\title{
Mild Versus Moderate Exercises on Inflammatory Cytokines in Type 2 Diabetes Mellitus Patients
}

\author{
HANY M.G. ABD EL-AZIZ, Ph.D. 1; ZAHRA M.H. SERRY, Ph.D. 1; DINA M. ABAZA, M.D.2; \\ NAGWA A. MOHAMMED, M.D. ${ }^{3}$ and GIHAN S. MOHAMED, Ph.D. 4
}

The Department of Physical Therapy for Cardiovascular/Respiratory Disorders and Geriatrics, Faculty of Physical Therapy, Cairo University1, The Department of Endocrinology and Metabolism, Faculty of Medicine, Al-Azhar University for Girls2, The Department of Clinical and Chemical Pathology, National Research Center ${ }^{3}$ and The Department of Physical Therapy, Faculty of Applied Medical Sciences, Umm Al-Qura University, Kingdom of Saudi Arabia4

\begin{abstract}
Background: Immunity is decreased in diabetic patient and exercise is an important method in decreasing inflammatory cytokines and increasing immunity.

Aim of Study: The main objective of this study was to determine the effect of mild exercise versus moderate exercise on inflammatory cytokines in patients with type 2 diabetes.

Subjects and Methods: 40 patients (men and women) diagnosed with type 2 diabetes (non-insulin dependant diabetes mellitus) age ranged from 50 to 60 years old. They were selected from medical health insurance clinic in Misr ElGedida during 2017. Theywere divided into two groups. Group A included 20 patients participated in mild exercise in form of 10 minute walking program 3 times weekly for two months and Group B 20 patients participated in a moderate exercise in form of 10 minute walking program 3 times weekly for two months. Blood sample for measuring inflammatory cytokines level (IL1 and IL6) were taken before and after exercise program.
\end{abstract}

Results: It showed that in most measures that rate of decrease of inflammatory cytokines in group B who participated moderate exercise is greater than Group A who participated mild exercise.

Conclusion: Participating exercise increases immunity by decreasing rate of inflammatory cytokines in patients with type 2 diabetes. Moderate exercise had a greater effect on decreasing inflammatory cytokines than mild exercise.

Key Words: Inflammatory cytokines - Type 2 diabetes mellitus - Mild and moderate exercise - Interleuikins.

\section{Introduction}

DIABETES is a chronic condition associated with abnormally high levels of sugar (glucose) in the blood. Insulin produced by the pancreas lowers

Correspondence to: Dr. Hany M.G. Abd El-Aziz,

The Department of Physical Therapy for Cardiovascular/ Respiratory Disorders and Geriatrics, Faculty of Physical Therapy, Cairo University blood glucose. Absence or insufficient production of insulin causes diabetes. The two types of diabetes are referred to as type 1 (insulin dependent) and type 2 (non-insulin dependent). Symptoms of diabetes include increased urine output, thirst and hunger as well as fatigue. Diabetes is diagnosed by blood sugar (glucose) testing [1]

There are two major types of diabetes, called type 1 and type 2. Type 1 diabetes was also formerly called Insulin Dependent Diabetes Mellitus (IDDM), or juvenile onset diabetes mellitus. In type 1 diabetes, the pancreas undergoes an autoimmune attack by the body itself, and is rendered incapable of making insulin. Abnormal antibodies have been found in the majority of patients with type 1 diabetes. Antibodies are proteins in the blood that are part of the body's immune system. The patient with type 1 diabetes must rely on insulin medication for survival [2].

In autoimmune diseases, such as type 1 diabetes, the immune system mistakenly manufactures antibodies and inflammatory cells that are directed against and cause damage to patients' own body tissues. In persons with type 1 diabetes, the beta cells of the pancreas, which are responsible for insulin production, are attacked by the misdirected immune system. It is believed that the tendency to develop abnormal antibodies in type 1 diabetes is, in part, genetically inherited, though the details are not fully understood [3]

Type 2 diabetes was also previously referred to as Non-Insulin Dependent Diabetes mellitus (NIDDM), or Adult Onset Diabetes Mellitus (AODM). In type 2 diabetes, patients can still produce insulin, but do so relatively inadequately 
for their body's needs, particularly in the face of insulin resistance as discussed above. In many cases this actually means the pancreas produces larger than normal quantities of insulin. A major feature of type 2 diabetes is a lack of sensitivity to insulin by the cells of the body (particularly fat and muscle cells) [4].

Mild cardiovascular exercise may take many forms, generally notable for low impact on joints and a relatively undemanding pace. For example, walking is a mild form of exercise, whether performed at a brisk or leisurely pace. Contrasted with running, it exerts far less impact on the knees and other joints. Along with walking, many examples of mild exercise form part of common daily routines. For example, walking up stairs is usually a mild exercise. Leisure activities, such as cycling, canoeing or swimming, also offer mild workouts, provided you practice them at a low to moderate intensity [5]

Exercise alone in weight loss produce marginal reduction in IL6 level in diabetic woman. However, previous studies in healthy, athletic individuals have reported increased local inflammation with intense exercise possibly attributed to microdamage of the active muscle tissue, moderate intensity exercise is recommended for either 30 minutes a day for 5 days a week or a total of 2 hours and 30 minutes per week. A moderate level of activity noticeably increases your heart rate and breathing rate. You may sweat, but you are still able to carry on a conversation. You can talk, but you can't sing. At least 10 minutes of continuous physical activity [6].

Interleukins are a group of cytokines (secreted proteins/signaling molecules) that were first seen to be expressed by white blood cells (leukocytes). The term interleukin derives from (inter-) "as a means of communication", and (-leukin) "deriving from the fact that many of these proteins are produced by leukocytes and act on leukocytes". The name is something of a relic though it has since been found that interleukins are produced by a wide variety of body cells. The function of the immune system depends in a large part on interleukins, and rare deficiencies of a number of them have been described, all featuring autoimmune diseases or immune deficiency. The majority of interleukins are synthesized by helper CD $4+\mathrm{T}$ lymphocytes, as well as through monocytes, macrophages, and endothelial cells. They promote the development and differentiation of T, B and hematopoietic cells [7].

\section{Subjects and Methods}

\section{Inclusive criteria:}

Patients have the following:

- Taking medical treatment for diabetes regularly with regular follow-up visits for outpatients clinic.

- Fasting blood glucose level above 160mg/dl.

- Patients initially diagnosed as type 2 diabetes with no signs for diabetic foot.

- Able to understand the purpose of exercise.

The study was conducted on 40 patients (men and women) diagnosed with type 2 diabetes (noninsulin dependant diabetes mellitus) age ranged from 50 to 60 years old. They were selected from Medical Health Insurance Clinic in Misr El-Gedida.

They were divided into two groups:

- Group (A): 20 patients participated in mild exercise in form of 10 minute walking program 3 times weekly for two months.

- Group (B): 20 patients participated in a moderate exercise in form of 10 minute walking program 3 times weekly for two months.

There were 5 minutes warm-up in form stretching exercise and also 5 minutes cool down exercise in form of stretching exercise for both groups of patients.

\section{Equipment:}

A- For evaluation: Blood sample for measuring inflammatory cytokines level (IL1 and IL6) before and after exercise program.

Serum IL-1 $\beta$ and IL-6 was estimated by a solid phase, two-site chemiluminescenceimmunometric assay by using an Immulite 1000 analyzer supplied from DPC (DPC Biermann GmbH, 61231 Bad Nauheim, Germany) [8].

\section{Training procedure:}

Group (A) twenty patients participated under supervised aerobic exercises program (mild exercise) in form of walking on motorized treadmail for 10 minutes performed 3 times per week for 2 months. Less tha $50 \%$ of their maximam heart rate.

Group (B) twenty patients participated under supervised aerobic exercises program (moderate exercise) in form of walking on motorized treadmail for 10 minutes performed 3 times per week for 2 months up to $50 \%$ to $60 \%$ of their maximam heart rate. 
- Maximam Heart Rate formula (MHR): Subtract your age from 220 to get your maximum heart rate.

- Next, subtract your resting heart rate from your maximum heart rate.

Multiply that number by your percentage of training intensity. Then add your resting heart rate to get your target heart rate.

There were 5 minutes warm-up in form stretching exercise and also 5 minutes cool down exercise in form of stretching exercise for both groups of patients.

\section{Statistical analysis:}

Data concerning each patient for both groups were collected in the first evaluation including, inflammatory cytokines (IL1 and IL6). These data were collected after 2 months after performing exercise for both groups in the final evaluation.

Descriptive analysis (mean \pm SD) before and after 2 months $t$-test were used in treatment of the data of the study and also between men and women.

\section{Results}

The mean difference value of group A is $2.850 \pm$ 0.366 while the mean difference value of group $B$ is $9.190 \pm 0.803$ which means that the rate of decrease of IL6 in group B is greater than group A.

Table (1): Comparison between pre and post values of IL6 within and between both groups.

\begin{tabular}{|c|c|c|c|c|}
\hline \multirow[b]{2}{*}{ IL-6 } & \multicolumn{2}{|c|}{ Group } & \multicolumn{2}{|c|}{$t$-test } \\
\hline & $\begin{array}{l}\text { Mild exercise } \\
\text { (Group A) }\end{array}$ & $\begin{array}{l}\text { Moderate } \\
\text { exercise } \\
\text { (Group B) }\end{array}$ & $t$ & $\underset{\text { value }}{p^{-}}$ \\
\hline \multicolumn{5}{|l|}{ Before: } \\
\hline Range & $10.6-16.7$ & $11.2-19$ & -3.308 & $0.002 *$ \\
\hline Mean $\pm S D$ & $13.580 \pm 1.792$ & $15.690 \pm 2.220$ & & \\
\hline \multicolumn{5}{|l|}{ After: } \\
\hline Range & $7.3-13.2$ & $4-9.1$ & 8.228 & $<0.001 *$ \\
\hline Mean \pm SD & $10.730 \pm 1.763$ & $6.500 \pm 1.476$ & & \\
\hline $\begin{array}{l}\text { Improvement } \\
\text { percentage }\end{array}$ & $100 \%$ & $100 \%$ & & \\
\hline \multicolumn{5}{|l|}{ Paired differences: } \\
\hline Mean \pm SD & $2.850 \pm 0.366$ & $9.190 \pm 0.803$ & & \\
\hline \multicolumn{5}{|l|}{ Paired samples test: } \\
\hline$t$ & 34.791 & 51.168 & & \\
\hline$p$-value & $<0.001 *$ & $<0.001 *$ & & \\
\hline
\end{tabular}

The mean difference value of group A is $5.975 \pm$ 0.271 while the mean difference value of group B is $7.990 \pm 0.658$ which means that the rate of decrease of IL-1B in group B is greater than group A.
Table (2): Comparison between pre and post values of IL 1B within and between both groups.

\begin{tabular}{|c|c|c|c|c|}
\hline \multirow[b]{2}{*}{ IL-1B } & \multicolumn{2}{|c|}{ Group } & \multicolumn{2}{|c|}{$t$-test } \\
\hline & $\begin{array}{c}\text { Mild } \\
\text { exercise } \\
\text { (Group A) }\end{array}$ & $\begin{array}{l}\text { Moderate } \\
\text { exercise } \\
\text { (Group B) }\end{array}$ & $t$ & $\underset{\text { value }}{p^{-}}$ \\
\hline \multicolumn{5}{|l|}{ Before: } \\
\hline Range & $8.4-12$ & $9.1-14.2$ & -3.391 & $0.002 *$ \\
\hline Mean \pm SD & $9.940 \pm 1.174$ & $11.445 \pm 1.600$ & & \\
\hline \multicolumn{5}{|l|}{ After: } \\
\hline Range & $2-6$ & $2-5$ & 1.468 & 0.150 \\
\hline Mean \pm SD & $3.965 \pm 1.221$ & $3.455 \pm 0.959$ & & \\
\hline $\begin{array}{l}\text { Improvement } \\
\text { percentage }\end{array}$ & $100 \%$ & $100 \%$ & & \\
\hline \multicolumn{5}{|l|}{ Paired differences: } \\
\hline Mean $\pm S D$ & $5.975 \pm 0.271$ & $7.990 \pm 0.658$ & & \\
\hline \multicolumn{5}{|l|}{ Paired samples test: } \\
\hline$t$ & 98.527 & 54.266 & & \\
\hline$p$-value & $<0.001 *$ & $<0.001 *$ & & \\
\hline
\end{tabular}

There were significant decrease in mean values of both groups after mild and moderate exercise. There were no significant difference between male and female patients. The rate of decrease of mean values in group B were greater than group A.

Table (3): Comparison between males and females IL6 mean values in both groups pre and post the study.

\begin{tabular}{lcccc}
\hline & \multicolumn{2}{c}{ Sex } & \multicolumn{2}{c}{$t$-test } \\
\cline { 2 - 5 } IL-6 & $\begin{array}{c}\text { Male } \\
\text { Mean } \pm \text { SD }\end{array}$ & $\begin{array}{c}\text { Female } \\
\text { Mean } \pm \text { SD }\end{array}$ & $t$ & $\begin{array}{c}p^{-} \\
\text {value }\end{array}$ \\
\hline $\begin{array}{l}\text { Group A mild } \\
\text { exercise: }\end{array}$ & & & & \\
$\quad$ Before & $13.400 \pm 2.087$ & $13.727 \pm 1.600$ & -0.397 & 0.696 \\
$\quad$ After & $10.478 \pm 1.965$ & $10.936 \pm 1.648$ & -0.568 & 0.577 \\
Group B moderate & & & & \\
exercise: & & & & \\
$\quad$ Before & $17.480 \pm 1.055$ & $13.900 \pm 1.473$ & 6.249 & $<0.001^{*}$ \\
$\quad$ After & $7.740 \pm 0.807$ & $5.260 \pm 0.728$ & 7.217 & $<0.001^{*}$ \\
\hline
\end{tabular}

There were no significant difference between male and female IL1B mean values in both groups pre and post the study.

Table (4): Comparison between males and females IL1B mean values in both groups pre and post the study.

\begin{tabular}{lllll}
\hline & \multicolumn{3}{c}{ Sex } & \multicolumn{2}{c}{$t$-test } \\
\cline { 2 - 5 } IL-1B & $\begin{array}{c}\text { Male } \\
\text { Mean } \pm \text { SD }\end{array}$ & $\begin{array}{c}\text { Female } \\
\text { Mean } \pm \text { SD }\end{array}$ & $t$ & $\begin{array}{c}p^{-} \\
\text {value }\end{array}$ \\
\hline $\begin{array}{l}\text { Group A mild } \\
\text { exercise: }\end{array}$ & & & & \\
$\quad$ Before & $9.833 \pm 1.333$ & $10.027 \pm 1.085$ & -0.359 & 0.724 \\
$\quad$ After & $3.722 \pm 1.477$ & $4.164 \pm 0.996$ & -0.796 & 0.436 \\
Group B moderate & & & & \\
exercise: & & & & \\
$\quad$ Before & $12.840 \pm 0.854$ & $10.050 \pm 0.595$ & 8.477 & $<0.001^{*}$ \\
$\quad$ After & $4.290 \pm 0.453$ & $2.620 \pm 0.434$ & 8.415 & $<0.001^{*}$ \\
\hline
\end{tabular}




\section{Discussion}

Diabetes Mellitus (DM), commonly referred to as diabetes, is a group of metabolic diseases in which there are high blood sugar levels over a prolonged period [2]. Symptoms of high blood sugar include frequent diabetes can cause many complications [3]. Acute complications can include diabetic ketoacidosis, nonketotic hyperosmolar coma, or death [4]. Serious long-term complications include heart disease, stroke, chronic kidney failure, foot ulcers, and damage to the eyes. Diabetes also cause Immune system deficiency.

The objective was to determine the effect of mild and moderate exercise on anti inflammatory cytokines (IL1B, IL6) in patients with type 2 diabetes. Analysis of the measurable data in both groups found improvement in decrease in both IL1B and IL6 in both groups with the favour for group B of moderate exercise, which can be explained according to previous studies as follows.

Miguel et al., [9] agreed that there is a reduction in plasma concentration of TNF- a, IL-6 and their receptors in soluble form have also been demonstrated in individuals with HF undergoing an aerobic training program, suggesting a reduction in the chronic inflammatory condition, mediated by a regulation in peripheral inflammatory response. However, despite the marked restorative and/or anti-inflammatory effect of exercise in these conditions, little is known about the possible mechanisms by which aerobic training can modulate this process.

Fischer [10] proposed hypothesis that the regular practice of physical exercise, organized as a training program, has an anti-inflammatory effect induced by acute multiple sessions, which leads to protection against chronic inflammatory conditions, especially by reducing the levels of pro-inflammatory cytokines and C-reactive protein. However, the possible mechanisms modulating this "beneficial" effect are not established and could be related both to an improvement in conditional physical capacity and a direct anti-inflammatory effect.

Hopps et al., [11] reported thatphysical exercise is known to reduce markers of inflammation by decreasing adipocytokine production and cytokine release from skeletal muscles, endothelial cells, and immune system and also improving antioxidant status. In type 2 diabetics, aerobic and resistance training have different effects on cytokine levels, and the differences in the modalities of exercise (type, duration, and intensity) and especially in the examined population could produce different results. Recent research showed that combined exercise has greater anti-inflammatory effects than aerobic or resistance exercise alone causing a deepest decrease in CRP, IL-6, IL-1 (3, TNF-a, leptin, and resistin and a higher increase in antiinflammatory cytokines such as IL-4, IL-10, and adiponectin.

Abd El-Kader et al., [12] studied the impact of mild versus moderate exercise effect on inflammatory cytokines in obese type 2 diabetic patients: A randomized clinical trial. He concluded that moderate aerobic exercise training modulate inflammatory cytokines more than mild aerobic exercise training in obese type 2 diabetic patients.

Yates et al., [13] examined effect of walking on inflammatory markers in patients with type 2 diabetes. He found that walking activity, independant of other forms of physical activity is associated with lowering levels of pro inflammatory markers.

\section{Conclusion:}

Exercise increases immunity by decreasing rate of inflammatory cytokines in patients with type 2 diabetes. Moderate exercise had a greater effect on decreasing inflammatory cytokines than mild exercise.

\section{References}

1- American Diabetes Association: Standards of medical care in diabetes-2014. Diabetes Care, 37 (Suppl 1): S14S80. Doi: 10.2337/dc14-S014. Accessed January 7, 2014.

2- NIX S.: Diabetes mellitus. In Williams' Basic Nutrition and Diet Therapy, 14th ed., pp. 400-25. St. Louis: Mosby, 2013.

3- HU E.A., PAN A., MALIK V. and SUN Q.: "White rice consumption and risk of type 2 diabetes: Meta-analysis and systematic review". B.M.J. (Clinical researched). 344: e1454. Doi: 10.1136/bmj.e1454. PMC 3307808. PMID 22422870, (2012-03-15).

4- LEE I.M., SHIROMA E.J., LOBELO F., PUSKA P., BLAIR S.N. and KATZMARZYK P.T.: "Effect of physical inactivity on major non-communicable diseases worldwide: An analysis of burden of disease and life expectancy". The Lancet 380 (9838): 21929. Doi: 10.1016/ S01406736(12)610319.PMC 3645500. PMID 22818936, (1 July 2012).

5- HILL J.: MayoClinic.com; Strength Training: Get Stronger, Leaner, Healthier, June 2010.

6- HASKELL W.L., LEE I.M., PATE R.R., et al.: Physical activity and public health: Updated recommendation for adults from the American College of Sports Medicine and the American Heart Association. Med. Sci. Sports Exerc., 39: 1423-34, 2007.

7- BARTHELMES K., REYNOLDS A.M., PEISACH E., JONKER H.R., DeNUNZIO N.J., ALLEN K.N., IMPERIALI B. and SCHWALBE H.: "Engineering encodable lanthanide-binding tags into loop regions of proteins". J. 
Am. Chem. Soc.. 133 (4): 808-19. Doi:10.1021/ja104983t, 2011.

8- BACCI M.R., LEME R.C.P., ZING N.P.C., MURAD N., ADAMI F., HINNIG P.F., FEDER D., CHAGAS A.C.P. and FONSECA F.L.A.: IL-6 and TNF-a serum levels are associated with early death in community-acquired pneumonia patients. Brazilian Journal of Medical and Biological Research, 48 (5): 427-32, 2015.

9- MIGUEL L., BATISTA J. and RENATO D.L.: Marília Cerqueira Leite Seelaender and Antonio Carlos Lopes II Arq. Bras.Cardiol. Vol. 93 No.6 São Paulo Dec., http://dx.doi.org/10.1590/S0066-782X2009001200021, 2009.

10- FISCHER C.P., PERSTRUP L.B., BERNTSEN A., ES-
KILDSEN P. and PEDERSEN B.K.: Elevated plasma interleukin-18 is a marker of insulin-resistance in type 2 diabetic and non-diabetic humans. Clin. Immunol., 117: 152-60, 2006.

11- HOPPS E., CANINO B. and CAIMI G.: Acta Diabetol., 48: 183. Doi: 10. 1007/s00592-011-0278-9, 2011.

12- ABD EL-KADER S.M., GARI A.M. and SALAH ELDEN A.E.M.: African Health Sciences, 13 (4): 857-63, http://dx.doi.org/10.4314/ahs.v13i4.1, 2013.

13- YATES T., KHUNTI K., BULL F., GORELY T. and DAVIES M.J.: The role of physical activity in the management of impaired glucose tolerance: A systematic review. Diabetologia, 50: 1116-26, 2008.

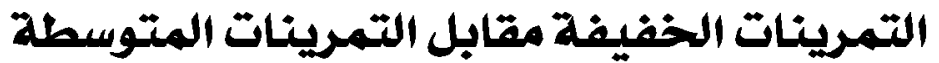

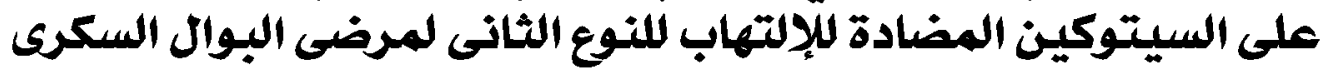

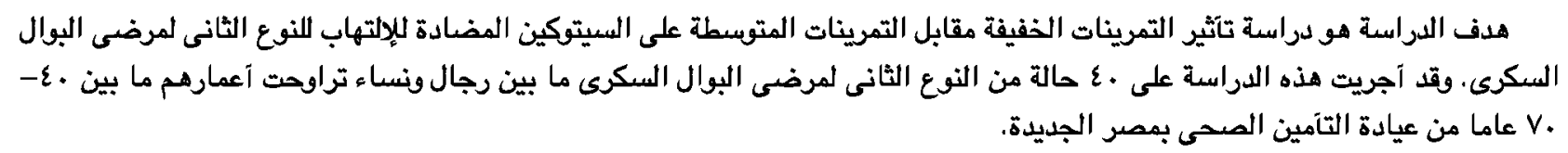

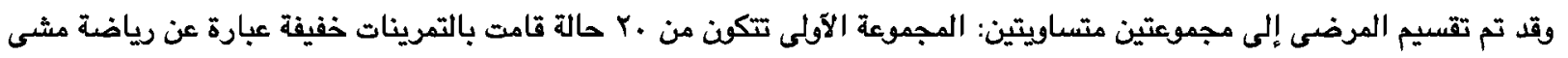

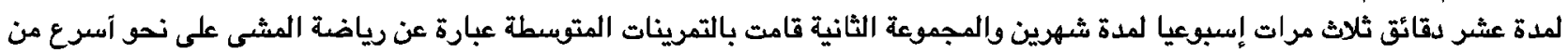

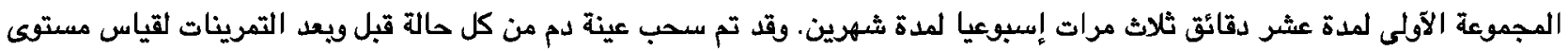

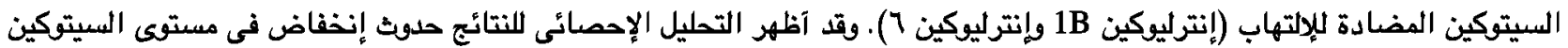

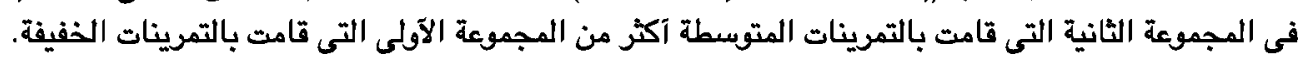

